\title{
Pastoral lessons from Augustine's theological correspondence with women
}

\begin{tabular}{|c|c|}
\hline $\begin{array}{l}\text { Authors: } \\
\text { Edward Smith }\end{array}$ & $\mathrm{er}^{1,2}$ \\
\hline $\begin{array}{l}\text { Affiliations: } \\
{ }^{1} \text { Department } \\
\text { Studies, Colur } \\
\text { International } \\
\text { United States }\end{array}$ & $\begin{array}{l}\text { of Intercultural } \\
\text { nbia } \\
\text { University, }\end{array}$ \\
\hline $\begin{array}{l}{ }^{2} \text { Department } \\
\text { and Science o } \\
\text { University of } \\
\text { South Africa }\end{array}$ & $\begin{array}{l}\text { of Missiology } \\
\text { f Religion, } \\
\text { Pretoria, }\end{array}$ \\
\hline $\begin{array}{l}\text { Project leade } \\
\text { Project numb }\end{array}$ & $\begin{array}{l}\text { : N. Niemandt } \\
\text { er: } 04317734\end{array}$ \\
\hline $\begin{array}{l}\text { Description: } \\
\text { Prof. Dr Smith } \\
\text { participating } \\
\text { project, 'Ecod } \\
\text { by Prof. Dr Ne } \\
\text { Department S } \\
\text { Religion and } \\
\text { Faculty of The } \\
\text { University of }\end{array}$ & $\begin{array}{l}\text { er is } \\
\text { n the research } \\
\text { omy', directed } \\
\text { lus Niemandt, } \\
\text { cience of } \\
\text { Missiology, } \\
\text { ology, } \\
\text { retoria. }\end{array}$ \\
\hline $\begin{array}{l}\text { Correspondin } \\
\text { Edward Smith } \\
\text { edsmither } 71\end{array}$ & $\begin{array}{l}\text { g author: } \\
\text { er, } \\
\text { Dgmail.com }\end{array}$ \\
\hline $\begin{array}{l}\text { Dates: } \\
\text { Received: } 13 \\
\text { Accepted: } 17 \\
\text { Published: } 19\end{array}$ & $\begin{array}{l}\text { Mec. } 2015 \\
\text { Mar. } 2016 \\
\text { Aug. } 2016\end{array}$ \\
\hline $\begin{array}{l}\text { How to cite th } \\
\text { Smither, E., } 2 C \\
\text { lessons from } \\
\text { theological co } \\
\text { with women', } \\
\text { Studies/Theol } \\
72(4), \text { a3288. } \\
\text { org/10.4102/l }\end{array}$ & $\begin{array}{l}\text { is article: } \\
\text { 16, 'Pastoral } \\
\text { lugustine's } \\
\text { rrespondence } \\
\text { HTS Teologiese } \\
\text { gical Studies } \\
\text { http://dx.doi. } \\
\text { tts.v72i4.3288 }\end{array}$ \\
\hline $\begin{array}{l}\text { Copyright: } \\
\text { (c 2016. The } \\
\text { Licensee: AOS } \\
\text { is licensed un } \\
\text { Creative Comr } \\
\text { Attribution Lic }\end{array}$ & $\begin{array}{l}\text { uthors. } \\
\text { IS. This work } \\
\text { der the } \\
\text { nons } \\
\text { ense. }\end{array}$ \\
\hline Read online: & \\
\hline 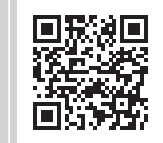 & $\begin{array}{l}\text { Scan this QR } \\
\text { code with your } \\
\text { smart phone or } \\
\text { mobile device } \\
\text { to read online. }\end{array}$ \\
\hline
\end{tabular}

Augustine of Hippo (354-430) was a fourth- and fifth-century monk-bishop who left a great imprint on the spiritual leaders of his day by overseeing the monastery at Hippo Regius and also authoring a significant corpus of letters that were pastoral in nature. What is often overlooked in the study of his pastoral ministry and, thus, the focus of this article, is Augustine's theological correspondence with 15 different women. Through surveying the themes and issues in these letters, I have endeavoured to show that, though a monk, Augustine did care for women in his pastoral ministry and his letters show that he discussed with women many of the issues of his day (pastoral issues, church matters, monastic ideas, theology, and practical theology) that he also discussed with his male correspondents. In short, Augustine believed that these women were much like his mother Monica - capable of grasping biblical and theological issues - and he valued them as an important part of the church. I conclude the article by summarising Augustine's approaches to and values for ministering to women.

\section{Introduction}

A key component of Augustine of Hippo's (354-430) pastoral ministry was mentoring and forming other Christians, particularly church leaders, through the medium of letters. For example, in his correspondence with other ordained clergy, he addressed theological issues, practical church matters, and even started on a few books through letters. In all, his corpus of letters adds up to 252 communications most of which were composed during his nearly 40 years as presbyter and bishop of Hippo (cf. Smither 2008:157-185). Letters in Augustine's day were not necessarily private conversations; rather, they served as a platform for Augustine and others to publish ideas and ultimately shape the direction of the church (cf. Conybeare 2005:57; Tilley 2005:41).

Another means in which Augustine mentored other Christians was through the monastery in which he lived in spiritual community with other men - initially with laymen and then later with other clergy - during this same period of his life in ministry (cf. Smither 2008:134-157). Women, of course, were not a part of these communities and, in fact, great care was taken to see that Augustine's monks did not succumb to temptation through interaction with the opposite sex.

Does this mean that Augustine's spiritual and mentoring influence on women was limited or nonexistent? Did he follow the general cultural tendencies of Roman Africa and regard women as inferior? As a pastor, did he view them as incapable of theological dialogue? To the contrary, Augustine maintained a stimulating correspondence with a number of women in which theological and spiritual matters were engaged with much depth. In this article, I will briefly explore these letters identifying the correspondents and discussing the theological issues involved. My aim is to show that as he engaged women on many of the theological and practical issues of his day, some of the key components of Augustine's spiritual formation of men can also be observed in his engagement with women, which would make Augustine innovative in his context. I conclude the article by summarising Augustine's approaches and values for spiritually mentoring women through the medium of letters.

\section{Monica}

Before entering into a discussion of Augustine's letters with women, it would be good to show a context and perhaps offer a framework for his spiritual and theological interactions with women by briefly recounting his relationship with his mother Monica. In the opening book of Confessions, Augustine prays, 'My mother did all she could to see that you my God, should be more truly my father than he [Patricius] was' (Confessions 1.11.17 in Boulding 2012). I have argued elsewhere that Monica mentored Augustine in at least four ways (cf. Smither 2008:93-99). Firstly, as a woman of prayer and tears, a godly wife to a hot-tempered and unfaithful husband, and a model to other 
young wives, Monica discipled Augustine through her holy example. Bowery rightly adds that as an exemplar of Christ, Monica was the 'portrayal of an ideal Christian' (Bowery 2007:79-80). Secondly, as a praying woman who did not have a great deal of tolerance for speculative discourse, Monica demonstrated for her son a commitment to practical Christian living. Thirdly, having initially kicked her son out of the house when he joined the Manicheans and then later joined Bishop Ambrose in standing against Arianism in Milan, she seemed committed to sound doctrine. Finally, through her daily example and by involving Augustine in regular worship gatherings in Tagaste, Monica directed her son through an informal Christian education at home.

Following Augustine's conversion near Milan in 386, Monica continued as a fellow traveller with Augustine in his spiritual journey. This is evident in her participation in the famous Cassiciacum dialogues in which she was able to 'dismiss a whole philosophical school in a single vulgar word' (Brown 2000:111). Aiming to show how Augustine valued his mother's presence and participation in philosophical, theological, and spiritual matters, I have previously written:

Monica's participation at Cassiciacum leads us to three conclusions. First, Augustine's intellectual world was open to his mother as he welcomed her to this community. The suggestion that this aspect of Augustine's life and faith was off-limits to his mother fails to take into consideration her presence at Cassiciacum. Second, contrary to the conclusions of some scholars, Monica had the capacity to participate in philosophical discussions. Though she had not read Plato or Vergil, the fact that she could contribute to a conversation and even bring it to a grinding halt meant that she had the intellectual capacity to understand what was being said. Her lack of formal education did not keep her from being able to reason and articulate. Third, her decision to contribute to the dialogues from a practical perspective of simple faith as opposed to adopting philosophical rhetoric showed that she placed greater value on the practical. (Smither 2008:95-96)

Augustine's regard for his mother finds further support in their shared experience at Ostia near Rome just prior to her death. Describing this deep spiritual ascent toward wisdom that was both intellectual and spiritual, Augustine records:

We stood ... alone conferring very intimately ... we inquired between ourselves in the light of the present truth, the Truth which is yourself, what the eternal life of the saints would be like ... higher still we mounted by inward thought and wondering discourse on your works, we arrived at the summit of our minds. (Confessions 9.23-24 in Boulding 2012)

Bowery helpfully adds that 'this passage of joint ascent ... attests to Augustine's belief that women and men have the same access to and experience of divine revelation' (Bowery 2007:77). Monica's role at both Cassiciacum and Ostia seems to show that Augustine valued her as his equal in spiritual matters and affirms that 'a woman can attain the same intellectual and spiritual insights about divinity as men' (Bowery 2007:76). While Maureen Tilley has argued that Augustine generally regarded women as inferior to men (2005:41), the Augustine and Monica narrative seems to offer a different perspective about Augustine's thoughts on women and their spiritual abilities.

\section{Letters}

With this back-story in mind, let us now explore Augustine's correspondence with women. In total, Augustine wrote 19 of his 252 letters to women. Though it is true that Augustine wrote another eight letters in which a husband and wife are addressed (Letters 25, 27, 31, 42, 45, 80, 95 to Paulinus and Therasia; Letter 127 to Armentarius and Paulina; cf. Eno 1999:298-310), he essentially addresses the husband in these communications. As we do not get a sense of his interaction with the women in these letters, they will not be included in the present study (cf. Conybeare 2005:58; Tilley 2005:42-43).

In each of the 19 noted letters, these are responses to women who had initiated toward him posing various questions about the Christian life, thought, and practice. Fifteen different women are mentioned by name and five individuals (Ithaca, Albina, Proba, Juliana, Fabiola) are the recipients of more than one letter. Three of his letters are addressed to groups of women, including Letter 211 addressed to the nuns of Hippo and Letter 126, which is written to three members of the same family that includes a man although a woman is the primary addressee. Not unlike the complete corpus of Augustine's letters, his correspondence with women can be grouped according to five major themes: pastoral, church matters, monastic thought, theology, and practical theology. As we will show, some letters addressed multiple themes.

\section{Pastoral}

Five of Augustine's letters to women are primarily pastoral in focus. Augustine wrote Letter 92 to Italica, a prominent Roman woman who had recently lost her husband. Beginning with words of consolation, he emphasises the hope of eternal life and assures Italica that she will know her husband better in heaven than she knew him on earth. At this point, the letter becomes more theological and he responds to her query whether believers and even unbelievers will be able to perceive God in bodily form in eternity (see also Augustine, Letter 147). Augustine argues that God is Spirit and will only be perceived spiritually by those with spiritual eyes in heaven. After offering this explanation and teaching, he encourages Italica to teach and rebuke others, accordingly, which gives us a sense of the ministry she had and the influence that Augustine assumed she had.

In a second letter to Italica, Letter 99, Augustine offers a single reply to three letters that Italica had sent him. Augustine spends a good bit of time expressing his disappointment in her and the church leaders at Rome for not sharing more about their hardships, brought on by the recent Vandal sack of the city. He wants to be able to weep and suffer with them and bring consolation by sharing their burden. He concludes the letter by expressing concern for Italica's children and sharing a brief perspective on the benefits that come from suffering. 
Augustine sends Letter 131 to Proba responding to her thoughts on how the body is corruptible and given to disease and is a burden to the soul. Affirming her thoughts, he reminds her that Jesus is a physical healer but that an eternal, future hope provides strength to endure health crises. Reflecting on Romans 8:28 ('that in all things God works for the good of those who love Him' [NIV]), he asserts that even evil can be turned into and even used for good, which should lead us to give thanks in all things.

In Letter 263, he addresses Sapida, a consecrated virgin, who is grieving the loss of her brother who had served as deacon in the church at Carthage. By indicating that he had received and would wear a tunic that she had originally made for her brother, he ministers to her in her grief. Encouraging her to grieve with a Christian's eternal hope, he writes, 'Your hope will not be stolen from you even if your love is now postponed for a time' (Letter 263.4 in Hill 2001-2005).

In a final brief letter that has pastoral aims, Augustine writes Letter 267 to Fabiola. He responds to her communicated desire to go to heaven and adds that what makes one person close to another is not physical proximity but the ability to share ideas.

\section{Church matters}

Three of Augustine's letters deal with issues facing the church. Letter 124 was addressed to Albina, Pinian, and Melania. Albina, the primary addressee, was a wealthy widow; Melania was her daughter; and Pinian was Albina's son-in-law. Following the Vandal conquest of Rome, the three had fled to Africa and were temporarily residing in Tagaste, Augustine's hometown, where his disciple Alypius was serving as bishop. In the brief letter, he communicates his desire to visit them but that he had been detained because of the harshness of winter and the great needs of the church at Hippo, particularly the struggle to maintain sound doctrine in the congregation.

In Letter 126, a follow-up letter addressed only to Albina, Augustine defends the church at Hippo against Albina's accusations that the church wanted to forcefully ordain her son-in-law Pinian in order to acquire his money. Though the church had wanted to compel Pinian toward ordination, Augustine ultimately did not allow it. As Albina's claims are levelled against the bishop and clergy of Hippo, Augustine takes great pains to clearly recount the events and appeal to God as his witness that he and the Hippo church are not driven by a love of money.

In a final letter dealing with church matters, Augustine writes Letter 20* to Fabiola. In this communication, he takes a good bit of space to recount the ordeal of the immoral Bishop Antoninus of Fussala, who had been a member of Augustine's monastery at Hippo and had been put forward by Augustine for ordination. As Fabiola would possibly be hosting or interacting with Antoninus, Augustine wanted her to be aware of what had transpired but to also be prepared to minister to Antoninus. Though Augustine had been forced to discipline and remove the bishop, it is still quite evident that he cared for his disciple from Hippo, and he regarded Fabiola as a co-labourer in this painful ministry. Finally, it seems that Augustine is also being cared for in this exchange, as he is able to share his own failure and grief with this female correspondent.

\section{Monastic thought}

Four of Augustine's letters to women address aspects of ascetic or monastic living. In Letter 150 to Proba and her daughter-in-law, Juliana, Augustine writes to congratulate the women when Juliana's daughter, Demetrias, decides to become a consecrated virgin. Augustine praises the young noblewoman for renouncing the prospect of marriage and family in order to bring glory to Christ and be an example to other young women.

In Letter 210, Augustine addresses Felicitas, the superior of the women's monastery at Hippo - a position that was initially occupied by Augustine's late sister. Offering practical advice to this spiritual leader of an ascetic community, Augustine relates that adversity and tribulation are gifts from God to purify us spiritually. He also devotes some space to discussing rebukes - that they are necessary and a blessing to the wise person, although they ought to be given in a way that leads to reconciliation.

Letter 211 is addressed to a group of women - the nuns of Hippo - who are experiencing conflict with their superior and are seeking to get her removed. Augustine uses the occasion of this letter to craft two small treatises on monastic living for nuns. In the first part of the letter (211.1-4), also known as a Reprimand for Quarreling Nuns (Obiurgatio), he lets them know that, as their bishop, he is not happy with their dissension, he longs for them to dwell in unity, and he reminds them that they do have good leaders. In part two of the letter (211.5-16), also referred to as a Rule for Nuns (Regularis Informatio), he offers teaching and instruction on monastic living. Beginning with a call to living together in unity and possessing all things in common, he urges them to pursue humility. From there, he covers a wide variety of subjects including prayer, fasting, table fellowship, and spiritual reading at table. He also discusses distributing food, clothing, and bedding according to the health needs of the women. He urges them to dress modestly, avoid potentially sinful contact with men, and pursue communal accountability toward holiness. He addresses washing clothes, bathing, and caring for the sick within the convent. Finally, he warns them against quarrelling, urges quick reconciliation, and commands the women to obey both their mother superior and the priest overseeing their community.

In a final letter related to ascetic practices, Letter 262, Augustine rebukes a laywoman named Ecdicia for embracing chastity and poverty without consulting her husband. Though her husband eventually agreed to chastity, he was unhappy with being forced into poverty and retaliated 
against his wife by committing adultery. Augustine rebukes Ecdicia for disrespecting and disobeying her husband in 'thoughtless haste' and holds up the biblical example of Esther as a woman of God who was even submissive to a non-believing husband. Finally, Augustine instructs her to apologise to her husband, pray for his repentance, and try to make amends on the property issue (cf. Tilley 2005:52).

\section{Theology}

In five of Augustine's letters to women, his primary focus was to address theological matters. Not surprisingly, these are the longest letters in his correspondence with women (cf. Tilley 2005:45). In Letter 147 to Paulina, which was a booklength treatise also published under the title On Seeing God (De vivendo Deo), Augustine picks up some of the same themes from his Letter 92 to Italica and addresses the question 'whether the invisible God can be seen by bodily eyes' (147.1.1). Augustine's theological value of faith seeking understanding is apparent at the beginning of the letter as he declares that we 'make more progress by thinking and praying than by reading and hearing' (Tilley 2005). That said, Augustine develops an argument to resolve the question by first distinguishing between believing God and seeing God. Appealing liberally to Ambrose's commentary on Luke's Gospel, Augustine affirms that the resurrected believer will continue to have a real body but that they will see God with spiritual eyes because they have clean hearts. For this same reason, it will be impossible for the wicked to perceive God because they will not be in his presence. Though Augustine appeals to both Ambrose and Jerome's teachings, he ultimately encourages Paulina to search the canonical Scriptures for herself on this question.

In Letter 188, Augustine, along with Alypius, writes a theologically oriented letter to Juliana, though it was actually directed toward the spiritual questions of her daughter, Demetrias. After praising Demetrias for her choice to take Christ as her husband, they warn her 'to avoid teachings opposed to the grace of God' (188.1.1-2, 3.14) because Juliana and Demetrias had reached out to Pelagius who had replied with a letter of his own to the women. Responding to Pelagius' teaching, Augustine and Alypius first challenge his notion of grace: 'that nature and doctrine are by themselves the grace and help of God for living righteously and correctly' (188.1.3). Further, they attempt to correct the teaching that a virgin might have 'reasons to believe that she has her virginal holiness and all her spiritual riches from herself alone' (188.2.4). Arguing from a litany of Scripture - some 50 direct quotes or allusions in a relatively short letter - they maintain that the gift and ability to be holy comes from God and not through works, so Demetrias' boasting should only be in the Lord.

Augustine addresses Letter 208 to Felicia, a consecrated virgin and a recent convert from Donatism. He responds to her letter regarding scandals in the church, particularly dealing with moral failure among church leaders. Though troubled by her disappointment with the clergy, Augustine reminds her not to be surprised because the Lord and the Apostle Paul had warned that these things would happen. Acknowledging that good and bad church leaders are part of the mixed elements of the church on earth, Augustine encourages her to put her hope in God in heaven rather than in the righteousness of earthly leaders. In short, through this letter to Felicia, Augustine summarises much of his ecclesiology, which was being developed in his polemic against the Donatists.

In Letter 264, Augustine writes to Maxima, a Spanish woman who was troubled by the Priscillianist heresy - a Manichean type teaching propagated by the fourth-century Spanish Bishop Priscillian (cf. Bassett 1999:949-950). Augustine encourages her not to be shocked by such teaching and to realise that God can actually use heresy to strengthen the church. He continues by briefly articulating an orthodox view of the incarnation of Christ. Though Augustine does address her concerns, he does not go into the theological depth that he does in other letters. This may have been because Maxima lacked the biblical and theological skills of Augustine's other female correspondents or, more likely, because she was already in contact with the Spanish presbyter Paul Orosius who came to Hippo in 414 to study with Augustine and gain biblical insights on the Priscillianist issue (cf. Teske 1999:684-685).

In a final theologically oriented letter, Augustine writes Letter 265 to Seleuciana, an African laywoman, and addresses her concerns with what appears to be Novatianist teaching. The Novatianists were a mid-third century rigorist group who opposed lapsed Christians being readmitted back into the communion of the church. Cyprian of Carthage (195-258) challenged their teaching and Augustine listed them in his work On Heresies (Da Haeresibus). Though Augustine seems unsure about the source of the teaching, he responds with surprise to the alleged teaching that Peter and the Apostles were never baptised, even though they were clearly engaged in baptising others according to Scripture. He also disposes of the false teaching that the 12 did not baptise but instead imposed a penance on their followers. Though the origin of the problematic teaching is not clear to Seleuciana or Augustine, he does serve her with a biblical response.

\section{Practical theology}

In two final letters, Augustine discusses matters of practical theology and Christian living. In Letter 130 to Proba, a widow whose deceased husband had been the richest man in Rome, Augustine writes a short treatise on the meaning of praying without ceasing (cf. Brown 2000:340; McWilliam 2007:196). Praising her for her desire to pray, he likens her to the desolate widow (1 Tm 5:5) whose primary calling has become persisting in prayer day and night. Though Proba is not economically poor, she has in a sense made herself poor to the world by putting her hope in eternal things.

Addressing the question of what to pray for, Augustine advises Proba to pray for the happy life (vita beata), which included having her needs for health, friendship, and material things met. Ultimately though, the happy life is a 
craving for eternal life and for the One who is able to give it (cf. McWilliam 2007:197).

Regarding how to pray, Augustine first mentions the attitude and posture of prayer - that we should pray believing that God is good and enjoys answering prayer. In other words, the values of faith, hope, and love ought to undergird one's approach to prayer. Practically speaking, Augustine urges Proba to pray with few words, emulating the Egyptian monks who were able to pray for long periods of time using short sentence prayers. This practice would lead to persistence in the discipline of prayer.

For Augustine, the best model for prayer was the Lord's Prayer. Arguing that it was a thorough and sufficient template for prayer and one that covers one's personal needs and those of friends, families, and even enemies, he writes: 'If you run though all the words of holy petitions, you will not find, in my opinion, anything that this prayer of our Lord does not contain and include' (130.12.22). Finally, Augustine added that fasting and almsgiving were useful practices in helping the believer to pray effectively and with focus.

Augustine concludes the letter by encouraging Proba to imitate the praying women of Scripture such as Hannah (1 Sm 1:2-28) and Anna (Lk 2:36-38) and he exhorts her to 'pray in hope; pray with faith and with love; pray persistently and patiently; pray like a widow for Christ ... though you are wealthy, pray as a poor woman' (130.14.30-31). Augustine closes the letter by asking Proba to pray for him.

In a second practically oriented communication, Augustine responds in Letter 266 to Florentina, a young African girl who writes inquiring about how to grow in wisdom and holiness. Augustine makes himself available to her and agrees to respond by letter to specific questions she might have. He admits that he is not a perfect teacher and is still making spiritual progress and that she should look to Christ the inner teacher in her pursuit of knowledge and wisdom.

\section{Conclusion}

So what can we conclude from this survey of Augustine's letters with women? Firstly, in terms of his posture toward women, Augustine was first and foremost a bishop responding to the needs of his flock while engaged in what he called the 'burden' of the ministry (sarcina episcopati). We are reminded that he did not make first contact with any of these correspondents (cf. Conybeare 2005:81; Tilley 2005:56). That said, Augustine was responsive, and women were a valued part of his pastoral focus.

Secondly, a related point, is that although Augustine was a bishop, he was also a monk; so his ascetic calling forbade close contact with women. Tilley seems to criticise Augustine for not pursuing the friendships (amicitia) with women that he enjoyed with men - through letter or any other means but it makes perfect sense that Augustine's monastic convictions would close the door to such relationships (cf. Tilley 2005:53, 57, 60). Indeed, a good portion of Augustine's The Rule: Precepts (Regula Praeceptum) provides instruction on how the monks should go out into public, where they might encounter women, how the members of the community should offer mutual accountability, and what steps should be taken if a monk fell into sexual temptation or sin (cf. The Rule 4:4-11). Vessey correctly notes that 'only at a distance, and by writing, could [Augustine] henceforth hold anything like a sustained conversation with a member of the opposite sex' (Vessey 2005:77). Given this necessary distance, I find it noteworthy and even remarkable that Augustine engaged women through letters to the extent that he did.

Thirdly, regarding his audience, Augustine corresponded with different types of women and he demonstrated skill in communicating with such a diverse group. Women like Albina, Proba, and Melania were wealthy members of the nobility who possessed some degree of authority and Augustine seemed comfortable relating to them (cf. Conybeare 2005:62; McWilliam 2007:196; Tilley 2005:43, 58). On the other hand, he was also able relate to lower class women, such as some members of the women's monastery at Hippo. Although his audience was diverse, one thing that united most of them was a common commitment to ascetic living.

Fourthly, it is interesting that Augustine included women in the biggest theological issues that he was facing as a bishop - Manicheanism, Donatism, Pelagianism, among others. His monastic letters to women also addressed many of the themes that he conveyed to monks. As his letters are saturated with verbatim biblical passages or allusions to Scripture, Augustine assumes that his female correspondents are well versed in the Bible and already have a good grasp of theology. Conybeare notes that these women had benefited from being educated, most likely at home, and were highly literate in Latin, which facilitated Augustine's interactions with them (cf. Conybeare 2005:59, 61). Finally, he expected women, just like men and just like his mother Monica, to be spiritually capable of responding to Christ, the inner teacher (cf. Vessey 2005:85).

Fifthly, Augustine's theological letters are contextual and occasioned by the real life issues facing these women and the church. As shown, Letter 147 to Paulina provides a platform to write a treatise on seeing God, while Letter 130 to Proba turns into a longer teaching on prayer. Out of his rebuke of the nuns of Hippo in Letter 211 emerges a monastic rule for women. As we have also shown, in Augustine's day, letters were not necessarily meant to be private conversations. So, did Augustine turn 'their appeals for pastoral help' into an 'outlet for publication of theology', as Tilley (2005:41) has argued? Although judging Augustine's motives is beyond the scope of a historical essay, it seems fair to conclude that Augustine used the occasion of a letter to women to teach the broader church, just as he had in over 200 other letters with men. Vessey helpfully summarises, 'Even when a letter is written with a larger readership in view than its addressee(s) ... the implied "original" context may still be a factor in the responses of real readers' (2005:74). 
In summary, the major themes addressed in Augustine's correspondence with women - pastoral issues, church matters, monastic thought, theology, and practical theology are quite consistent with the issues treated in the broader corpus of Augustine's letters (McWilliam 2007:189). Again, like Monica, he valued these women as correspondents and conversation partners on key theological and practical issues. McWilliam rightly adds, 'Augustine took the women and the issues and questions contained in their letters seriously. $\mathrm{He}$ thinks them capable ... of deep and prayerful spiritual lives but also of sound practical judgment' (2007:190). Thus, as he cared for the needs of the entire family of God - including the women surveyed in this study - it is not a stretch to conclude that Augustine, the monk-bishop, was also Augustine, a spiritual mentor to women.

\section{Acknowledgements Competing interests}

The author declares that he has no financial or personal relationships which may have inappropriately influenced him in writing this article.

\section{References}

Augustine, 2001-2005, Letters, transl. E. Hill, New City Press, New York.

Augustine, 2012, Confessions, transl. M. Boulding, New City Press, New York.

Bassett, P.M., 1999, 'Priscillian (ca. 340-ca. 387)', in E. Ferguson (ed.), Encyclopedia of early Christianity, pp. 949-950, Routledge, London.

Bowery, A.M., 2007, 'Monica: The feminine face of Christ', in J.C. Stark (ed.), Feminist interpretations of Augustine, pp. 69-95, Penn State University Press, State College, PA.

Brown, P.L., 2000, Augustine of Hippo: A biography, University of California Press, Berkley, CA.

Conybeare, C., 2005, 'Spaces between letters: Augustine's correspondence with women', in L. Olson \& K. Kerby-Fulton (eds.), Voices in dialogue: Reading women in the Middle Ages, pp. 57-72, University of Notre Dame Press, Notre Dame, IN.

Eno, R.B., 1999, 'Epistulae, 298-310', in A.D. Fitzgerald (ed.), Augustine through the ages: An encyclopedia, pp. 298-310, Eerdmans, Grand Rapids, MI.

McWilliam, J., 2007, 'Augustine's letters to women', in J.C. Stark (ed.), Feminist interpretations of Augustine, pp. 189-202, Penn State University Press, State College, PA.

Smither, E.L., 2008, Augustine as mentor: A model for preparing spiritual leaders, B\&H Academic, Nashville, TN.

Teske, R.J., 1999, 'Priscillianistas, Contra', in A.D. Fitzgerald (ed.), Augustine through the ages: An encyclopedia, pp. 684-685, Eerdmans, Grand Rapids, MI.

Tilley, M., 2005, 'No friendly letters: Augustine's correspondence with women', in D.B. Martin \& P.C. Miller (eds.), The cultural turn in late ancient studies, pp. 40-62, Duke University Press, Durham, NC.

Vessey M 2005, 'Response to Catherine Conybeare: Women of letters?' in L. Olson \& K. Kerby-Fulton (eds.), Voices in dialogue: Reading women in the Middle Ages, pp. 73-96, University of Notre Dame Press, Notre Dame, IN. 